AGRICULTURE AND BIOLOGY JOURNAL OF NORTH AMERICA

ISSN Print: 2151-7517, ISSN Online: 2151-7525, doi:10.5251/abjna.2012.3.4.169.174

C 2012, ScienceHu $\beta$, http://www.scihub.org/ABJNA

\title{
In-vitro antimicrobial activities of Euphorbia hirta against some clinical isolates
}

\author{
Kareem Kehinde Titilope ${ }^{1}$, Ezeh Abimbola Rashidat ${ }^{2}$, Obi Chioma Christiana ${ }^{2}$, \\ Egberongbe Rafiat Kehinde ${ }^{1}$, Jabbar Nasirudeen Omobolaji ${ }^{3}$ and Awoyera Jubril \\ Olajide $^{3}$
}

\author{
${ }^{1}$ Citrus Improvement Programme, National Horticultural Research Institute, \\ Ibadan, Oyo State, Nigeria. \\ 2 Department of Microbiology, University of Lagos, Nigeria. \\ ${ }^{3}$ Department of Microbiology, University of Agriculture, Abeokuta, Nigeria.
}

\begin{abstract}
This study was carried out to investigate the antibacterial activities of both ethanol and water extracts of Euphorbia hirta against some pathogens: Escherichia coli, Haemophilus influenzae, Klebsiella pneumoniae, Proteus vulgaris, Pseudomonas aeruginosa, Staphylococcus aureus, Salmonella typhi and Shigella dysenteriae. The agar diffusion method was used to determine the antibacterial activities of the extracts against the pathogens while the minimum inhibitory concentration (MIC) was determined by graphical method. Antibacterial sensitivity test indicated that the extracts of $E$. hirta inhibited the growth of all the organisms to varying degree. Significantly little or no zone of inhibition was observed when $E$. hirta extracts were tested on $H$. influenzae. Dry leaf extracts of $E$. hirta produced the highest zones of inhibition on Salmonella typhi. The dry extracts produced MIC values ranging between $2.78 \mathrm{mg} / \mathrm{ml}$ to $41.92 \mathrm{mg} / \mathrm{ml}$ for all the organisms while that of the fresh ethanol extracts ranged from $0.27 \mathrm{mg} / \mathrm{ml}$ to $20.13 \mathrm{mg} / \mathrm{ml}$.
\end{abstract}

Key words: Euphorbia hirta, ethanolic extract, agar diffusion, inhibition, antibacterial.

\section{INTRODUCTION}

Herbal medicine has been used in many parts of the world as a rich tradition for the treatment of many infectious diseases (Brantner and Grein 1994). In developing countries, it is estimated that about $80 \%$ of the population rely on traditional medicine for their primary health care (Matu and Van Staden 2003), because of better cultural acceptability, better compatibility with the human body and fewer side effects. However, the last few years have seen a major increase in their use in the developed world (Jigna et al., 2005). Medicinal herbs have curative properties due to presence of various complex chemical substance of different composition, which are found as secondary plant metabolites in one or more parts of these plants (Kumar et al., 2010). These plant metabolites according to their composition are grouped as alkaloids, glycosides, corticosteroids, essential oils etc. Euphorbia hirta, is an herb found in many parts of the world (Patil et al., 2009; Ogueke et al., 2007). Euphorbia hirta belongs to the family Euphorbiaceae. It is a small annual herb common to tropical countries (Soforowa, 1982). The plant has been used for female disorders but is now more important in treating respiratory ailments, especially cough, coryza, bronchitis and asthma. In India it is used to treat worm infestations in children and for dysentery, gonorrhea, jaundice, pimples, digestive problems and tumors (Kartikar and Basu, 1991). The plant is also widely used in Angola against diarrhea and dysentery, especially amoebic dysentery. In Nigeria extracts or exudates of the plant are used as ear drops and in the treatment of boils, sore and promoting wound healing (Igoli et al., 2005, Annon, 2005). The alcoholic extract of Euphorbia hirta leaves is highly effective against gram positive bacteria and moderately effective against gram negative bacteria. This work was carried out to determine the in-vitro activities of Euphorbia hirta extracts on some clinical isolates.

\section{MATERIALS AND METHODS}

Sample Collection: Fresh leaves of E. hirta were obtained from wild strands of $E$. hirta at University of Agriculture, Abeokuta (UNAAB), Nigeria. The taxonomic identities of these plants were confirmed in the Department of Biological Sciences. 
Sources of Test Organisms: The test organisms used for the study were Escherichia coli, Shigella dysenteriae, Pseudomonas aeruginosa, Staphylococcus aureus, Klebsiella pneumoniae, Proteus vulgaris, Haemophilus influenzae and Salmonella typhi. These organisms were clinical isolates from Federal Medical Centre, Idi-Aba, Abeokuta and Sacred Heart Hospital, Lantoro, Abeokuta. These organisms were re-identified using the standard techniques as described by Cowan and Steel (1965). They were subcultured on nutrient agar slants and stored at $4^{0} \mathrm{C}$ until required for the study.

\section{Sample Preparation and Extraction Procedure:} The leaves of $E$. hirta were washed after collection and later air-dried, powdered and stored in an airtight container until required.

Extraction from fresh and dry leaves of $E$. hirta was done with water and ethanol $(50 \%)$. The mixture was left for an extended period; the extract was filtered and left for 48 hours at room temperature according to the method described by (Ndip et al., 2009). $5 \mathrm{~g}$ of extract was dissolved in $50 \mathrm{ml}$ of water and ethanol; this gave $100 \mathrm{mg} / \mathrm{ml}$. Thereafter two fold serial dilutions were made from the original stock of $50 \mathrm{ml}$ (containing $100 \mathrm{mg} / \mathrm{ml}$ ), according to the method described by Akujobi et al., (2004), using the solvents to obtain the following concentrations: $100 \mathrm{mg} / \mathrm{ml}$, $50 \mathrm{mg} / \mathrm{ml}, 25 \mathrm{mg} / \mathrm{ml}, 12.5 \mathrm{mg} / \mathrm{ml}$ and $6.3 \mathrm{mg} / \mathrm{ml}$ which were used for the antimicrobial sensitivity test.

Determination of Antimicrobial Assay: The antimicrobial assay was performed using the agar well diffusion method described by (Ndip et al., 2009; Ogueke et al., 2007) for both the aqueous and ethanol extract. The molten nutrient agar were separately inoculated with $1.5 \times 10^{5} \mathrm{cfu} / \mathrm{ml}$ of the different test organisms from overnight broth cultures and poured into Petri dishes and then allowed to solidify. Wells were prepared in the seeded plates with the help of a cork borer $(10 \mathrm{~mm}) .100 \mu$ l of the extract was introduced into the wells.

The plates were pre- incubated for one hour to allow diffusion of extract before incubating overnight at $37^{\circ} \mathrm{C}$ for $24 \mathrm{hrs}$. The zones of inhibition that developed were measured in $\mathrm{mm}$. The average of the zones of inhibition was calculated.

$\begin{array}{llrr}\text { Determination of } & \text { Minimum } & \text { Inhibitory } \\ \text { Concentration: } & \text { The } & \text { minimum } & \text { inhibitory } \\ \text { concentration (MIC) } & \text { was } & \text { calculated by plotting the }\end{array}$

natural logarithm of the concentration of extract against the square of zones of inhibition.

A regression line was drawn through the points. The antilogarithm of the intercept on the logarithm of concentration axis gave the MIC values (Osadebe and Ukwueze, 2004; Ogueke et al., 2007).

\section{RESULTS}

Determination of Antimicrobial Assay

Dry Leaf aqueous and ethanol extract: The antimicrobial activities of E. hirta were assessed using the agar well diffusion method. All the pathogens used in this study were susceptible to both ethanol and aqueous extracts of dry leaf of Euphorbia hirta, the only exception was Haemophilus influenzae which was resistant to the ethanol extracts at concentrations of $6.3,12.5$ and $25 \mathrm{mg} / \mathrm{ml}$.

The results indicated that at $100 \mathrm{mg} / \mathrm{ml}$, aqueous extracts of the leaf produced the highest significant zone of inhibition $(19.00 \mathrm{~mm})$ on Pseudomonas aeruginosa while the least zone of inhibition was observed on Haemophilus influenzae with an average value of $3.67 \mathrm{~mm}$. This is shown on Table 1 . Similarly, the effect of the ethanolic extracts of the leaf on Haemophilus influenzae produced the least significant zone of inhibition. However, the highest effect was shown on Salmonella typhi with mean values ranging from 13.33 to $18.33 \mathrm{~mm}$ at different concentrations. The highest effects of ethanol and aqueous extracts were observed at the highest concentration of $100 \mathrm{mg} / \mathrm{ml}$ while the least effect was seen in the smallest concentration of $6.3 \mathrm{mg} / \mathrm{ml}$.

No significant difference was observed on the susceptibility of Klebsiella, E. coli, Shigella spp and Proteus sp. to aqueous extract of $E$. hirta at $100 \mathrm{mg} / \mathrm{ml}$. However, the susceptibility of these organisms was significantly lower than those of $P$. aeruginosa and Salmonella spp. Higher values ranging from 14.00 to $15.33 \mathrm{~mm}$ were observed at $100 \mathrm{mg} / \mathrm{ml}$ while lower values ranging from 6.33 to $13.33 \mathrm{~mm}$ were observed at $6.3 \mathrm{mg} / \mathrm{ml}$. 
Agric. Biol. J. N. Am., 2012, 3(4): 169-174

Table 1: Effect of aqueous and ethanolic dry leaf extracts of Euphorbia hirta against some pathogens.

\begin{tabular}{|c|c|c|c|c|c|c|c|c|c|c|}
\hline \multicolumn{11}{|c|}{ Concentration (mg/ml) } \\
\hline Organisms & \multicolumn{2}{|l|}{100} & \multicolumn{2}{|l|}{50} & \multicolumn{2}{|c|}{25} & \multicolumn{2}{|l|}{12.5} & \multicolumn{2}{|l|}{6.3} \\
\hline & Water & Ethanol & Water & Ethanol & Water & Ethanol & Water & Ethanol & Water & Ethanol \\
\hline E. coli & $6.67^{d}$ & $10.00^{\mathrm{bc}}$ & $8.33^{b}$ & $12.67^{\mathrm{ab}}$ & $5.00^{d}$ & $15.33^{\mathrm{a}}$ & $6.33^{\mathrm{bc}}$ & $11.00^{\mathrm{bc}}$ & $5.67^{e}$ & $9.33^{b}$ \\
\hline H. influenzae & $3.67^{\mathrm{e}}$ & $5.67^{d}$ & $3.33^{\mathrm{C}}$ & $2.67^{\mathrm{C}}$ & $2.00^{\mathrm{e}}$ & $0.00^{\mathrm{e}}$ & $2.00^{\mathrm{d}}$ & $0.00^{d}$ & $1.33^{\dagger}$ & $0.00^{c}$ \\
\hline K. pneumoniae & $6.67^{\mathrm{d}}$ & $6.33^{\mathrm{cd}}$ & $9.33^{\mathrm{b}}$ & $11.00^{\mathrm{ab}}$ & $9.67^{\mathrm{bc}}$ & $15.00^{\mathrm{a}}$ & $6.00^{c}$ & $12.67^{\mathrm{D}}$ & $9.67^{\mathrm{cd}}$ & $9.00^{b}$ \\
\hline P. aeruginosa & $19.00^{\mathrm{a}}$ & $13.00^{\mathrm{ab}}$ & $17.69^{\mathrm{a}}$ & $12.00^{\mathrm{ab}}$ & $15.67^{\mathrm{a}}$ & $11.67^{\mathrm{bc}}$ & $12.67^{\mathrm{a}}$ & $8.33 b^{c}$ & $15.00^{\mathrm{a}}$ & $6.33^{b}$ \\
\hline P. vulgaris & $8.33^{\mathrm{d}}$ & $14.33^{\mathrm{a}}$ & $8.00^{\mathrm{bc}}$ & $12.00^{\mathrm{ab}}$ & $9.00^{\mathrm{bc}}$ & $12.33^{b}$ & $9.33^{\mathrm{C}}$ & $10.67^{\mathrm{bc}}$ & $10.67^{\mathrm{C}}$ & $8.00^{b}$ \\
\hline Shigella dysenteriae & $8.67^{\mathrm{d}}$ & $14.00^{\mathrm{a}}$ & $8.00^{\mathrm{bc}}$ & $13.33^{\mathrm{ab}}$ & $7.67^{\mathrm{C}}$ & $9.33^{c}$ & $5.67^{\mathrm{C}}$ & $8.00^{\mathrm{bc}}$ & $8.00^{\mathrm{d}}$ & $7.00^{b}$ \\
\hline Staphylococcus aureus & $13.33^{\mathrm{C}}$ & $14.33^{\mathrm{a}}$ & $11.33^{\mathrm{b}}$ & $9.67^{b}$ & $9.33^{\mathrm{bc}}$ & $6.33^{\mathrm{d}}$ & $7.67^{\text {bc }}$ & $6.33^{\mathrm{C}}$ & $5.67^{\mathrm{e}}$ & $6.67^{\mathrm{b}}$ \\
\hline Salmonella typhi & $16.67^{b}$ & $15.33^{\mathrm{a}}$ & $17.67^{\mathrm{a}}$ & $15.00^{\mathrm{a}}$ & $11.67^{\mathrm{D}}$ & $17.33^{\mathrm{a}}$ & $12.67^{\mathrm{a}}$ & $18.33^{\mathrm{a}}$ & $13.00^{\mathrm{b}}$ & $13.33^{\mathrm{a}}$ \\
\hline
\end{tabular}

Values are means of triplicate readings.

On each column, means followed by different letters are significantly different $(P=0.05)$ according to Duncan's multiple range test.

Table 2: Effect of aqueous and ethanolic fresh leaf extracts of Euphorbia hirta against some pathogens.

\begin{tabular}{|c|c|c|c|c|c|c|c|c|c|c|}
\hline \multicolumn{11}{|c|}{ Concentration (mg/ml) } \\
\hline Organisms & \multicolumn{2}{|c|}{$100 \mathrm{mg} / \mathrm{ml}$} & \multicolumn{2}{|c|}{$50 \mathrm{mg} / \mathrm{ml}$} & \multicolumn{2}{|c|}{$25 \mathrm{mg} / \mathrm{ml}$} & \multicolumn{2}{|c|}{$12.5 \mathrm{mg} / \mathrm{ml}$} & \multicolumn{2}{|c|}{$6.3 \mathrm{mg} / \mathrm{ml}$} \\
\hline & Water & Ethanol & Water & Ethanol & Water & Ethanol & Water & Ethanol & Water & Ethanol \\
\hline E. coli & $11.67^{\mathrm{ab}}$ & $13.33^{b}$ & $9.00^{\mathrm{a}}$ & $10.33^{\mathrm{abc}}$ & $8.33^{\mathrm{bc}}$ & $9.33^{\mathrm{a}}$ & $10.00^{b}$ & $8.00^{\mathrm{ab}}$ & $9.67^{\mathrm{a}}$ & $7.00^{\mathrm{bc}}$ \\
\hline H. influenzae & $0.00^{\mathrm{d}}$ & $0.00^{\mathrm{e}}$ & $0.00^{c}$ & $2.00^{\mathrm{e}}$ & $0.00^{\mathrm{e}}$ & $1.67^{\mathrm{C}}$ & $0.00^{\mathrm{e}}$ & $1.33^{\mathrm{C}}$ & $0.00^{b}$ & $0.00^{\mathrm{d}}$ \\
\hline K. pneumoniae & $8.67^{\mathrm{bc}}$ & $15.00^{\mathrm{a}}$ & $9.33^{\mathrm{a}}$ & $12.67^{\mathrm{a}}$ & $6.67^{\mathrm{bc}}$ & $8.67^{\mathrm{ab}}$ & $6.00^{c}$ & $7.33^{b}$ & $3.00^{b}$ & $6.33^{c}$ \\
\hline$P$. aeruginosa & $13.33^{\mathrm{a}}$ & $12.00^{\mathrm{C}}$ & $7.67^{\mathrm{a}}$ & $11.33^{\mathrm{ab}}$ & $10.00^{\mathrm{ab}}$ & $9.67^{\mathrm{a}}$ & $7.33^{\mathrm{C}}$ & $9.67^{\mathrm{a}}$ & $9.33^{\mathrm{a}}$ & $9.67^{\mathrm{a}}$ \\
\hline P. vulgaris & $9.33^{b c}$ & $14.67^{\mathrm{a}}$ & $9.67^{a}$ & $10.33^{\mathrm{abc}}$ & $12.67^{\mathrm{a}}$ & $9.00^{\mathrm{ab}}$ & $21.00^{\mathrm{a}}$ & $8.00^{\mathrm{ab}}$ & $11.00^{\mathrm{a}}$ & $8.00^{b}$ \\
\hline Shigella dysenteriae & $10.00^{\mathrm{bc}}$ & $9.33^{d}$ & $10.00^{a}$ & $7.67^{\mathrm{cd}}$ & $8.00^{b c}$ & $6.67^{D}$ & $6.33^{\mathrm{C}}$ & $6.33^{b}$ & $7.33^{a}$ & $6.00^{C}$ \\
\hline Staphylococcus aureus & $8.00^{c}$ & $9.00^{d}$ & $8.00^{\mathrm{a}}$ & $7.33^{d}$ & $6.00^{\text {cd }}$ & $7.33^{\mathrm{ab}}$ & $10.00^{b}$ & $7.67^{\mathrm{ab}}$ & $11.67^{\mathrm{a}}$ & $6.67^{\mathrm{bc}}$ \\
\hline Salmonella typhi & $7.33^{c}$ & $11.33^{\mathrm{C}}$ & $3.67^{b}$ & $9.33^{\mathrm{bc}}$ & $3.00^{\mathrm{de}}$ & $8.67^{\mathrm{ab}}$ & $3.33^{\mathrm{d}}$ & $7.67^{\mathrm{ab}}$ & $2.67^{b}$ & $6.33^{c}$ \\
\hline
\end{tabular}

Values are means of triplicate readings.

On each column, means followed by different letters are significantly different $(P=0.05)$ according to Duncan's multiple range test. 
Fresh Leaf aqueous and ethanol extract: The results of the antibacterial screening of the different concentrations of the fresh leaves extract on the test isolates are shown on Table 2. The ethanolic extract was compared with the aqueous extract and the result showed that more than $60 \%$ of microorganisms were susceptible to the ethanolic extract of the fresh leaves. Amongst all the microorganisms used, $H$. influenzae exhibited the highest resistance to the extract while Salmonella spp. showed the least resistance.

Of all the concentrations with ethanolic extracts, the largest zones of inhibition were obtained at $100 \mathrm{mg} / \mathrm{ml}$ while the least was obtained at $6.3 \mathrm{mg} / \mathrm{ml}$.

Aqueous extract of the fresh leaves at $100 \mathrm{mg} / \mathrm{ml}$, had effects on $P$. aeruginosa as the most susceptible bacterium, followed by $S$. typhi and $S$. aureus while $H$. influenzae was the least susceptible. However with ethanolic extracts Klebsiella pneumoniae showed the highest zone of inhibition of $15.00 \mathrm{~mm}$ while no significant difference was observed in Shigella dysenteriae and Staphylococcus aureus. At all concentrations, $H$. influenzae was the least susceptible. Using the $12.5 \mathrm{mg} / \mathrm{ml}$, the maximum antibacterial activity was shown on Proteus vulgaris while lowest effectiveness exhibited on Haemophilus influenzae.

The aqueous extract had widest zone of inhibition on the isolates compared to the ethanolic extracts at $6.3 \mathrm{mg} / \mathrm{ml}$ while, no significant difference was seen in E. coli, K. pneumoniae, $P$. vulgaris , $S$. dysenteriae and Staphylococcus aureus .

Minimum Inhibitory Concentrations of Ethanolic and Aqueous Extracts of Euphorbia hirta: The minimum inhibitory concentration (MIC) was calculated by plotting the natural logarithm of the concentration of extract against the square of zones of inhibition.

A regression line was drawn through the points. The antilogarithm of the intercept on the logarithm of concentration axis gave the MIC values (Simone et al., 1998, Osadebe and Ukwueze, 2004).

The MIC was produced against Pseudomonas aeruginosa with a concentration of $0.27 \mathrm{mg} / \mathrm{ml}$ by using the ethanolic extract of fresh leaf while the highest MIC was against Haemophilus influenzae with a concentration of $20.13 \mathrm{mg} / \mathrm{ml}$. On dry leaf, the lowest MIC was produced against $P$. vulgaris with concentration of $1.64 \mathrm{mg} / \mathrm{ml}$ while the highest MIC was against $K$. pneumoniae with a concentration of $41.92 \mathrm{mg} / \mathrm{ml}$. For the aqueous extract, the highest minimum inhibitory concentration of dried leaf was exhibited against P.vulgaris while $H$. influenzae showed resistance against the fresh extracts. This is shown on Table 3.

Table 3: Minimum Inhibition Concentration (MIC)

\begin{tabular}{|c|c|c|c|c|}
\hline & \multicolumn{2}{|c|}{$\begin{array}{l}\text { Ethanolic Extract } \\
(\mathrm{mg} / \mathrm{ml})\end{array}$} & \multicolumn{2}{|c|}{$\begin{array}{l}\text { Water } \\
\text { Extract(mg/ml) }\end{array}$} \\
\hline & $\begin{array}{l}\text { Fresh } \\
\text { leaves }\end{array}$ & $\begin{array}{l}\text { Dry } \\
\text { leaves }\end{array}$ & $\begin{array}{l}\text { Fresh } \\
\text { leaves }\end{array}$ & $\begin{array}{l}\text { Dry } \\
\text { leaves }\end{array}$ \\
\hline S. typhi & 2.06 & 2.78 & 11.10 & 24.00 \\
\hline $\begin{array}{l}\text { S. } \\
\text { dysenteriae }\end{array}$ & 1.87 & 4.22 & 1.98 & 2.94 \\
\hline P. vulgaris & 5.15 & 1.64 & 45.11 & 74.73 \\
\hline E. coli & 3.40 & 15.95 & 4.48 & 6.29 \\
\hline S. aureus & 0.64 & 8.42 & 126.28 & 4.03 \\
\hline $\begin{array}{l}P . \\
\text { aeruginosa }\end{array}$ & 0.27 & 2.85 & 7.23 & 10.60 \\
\hline $\begin{array}{l}K . \\
\text { pneumoniae }\end{array}$ & 5.79 & 41.92 & 4.87 & 51.48 \\
\hline H. influenzae & 20.13 & 15.15 & NIL & 6.18 \\
\hline
\end{tabular}

\section{DISCUSSION}

The results obtained indicated that both ethanolic and aqueous extracts of the leaves of Euphorbia hirta inhibited the growth of the isolates used. All the organisms tested were susceptible to both ethanol and water extracts at different concentrations of $E$. hirta with the exception of $H$. influenzae which was not susceptible in few cases. This therefore shows that the extract contains substance(s) that can inhibit the growth of some microorganisms. Other workers have also shown that extracts of plants inhibit the growth of various microorganisms at different concentrations ( Ogueke et al., 2007;Akujobi et al., 2004; Nweze et al., 2004, Osadebe and Ukwueze, 2004; Simone et al., 1998).

Results obtained from dry ethanolic extracts showed that ethanol was better for extraction than water. This is in agreement with the report of Boer et al., 2005 that stated that active components of plants are more soluble in organic solvent.

This finding also agrees with previous report of Okwori et al., 2007 who reported ethanol to be the best solvent for the extraction of most plant active ingredients of medical importance. The high susceptibility of the enteric pathogens to the ethanol and not aqueous extracts of the dry leaves may 
further support the possibility that the active ingredients may be alkaloid or essential oils (Draughon, 2004). The inability of the extract to inhibit Haemophilus influenzae may be because it possesses a mechanism for detoxifying the active ingredients in the extract. Some bacteria are known to possess mechanisms in which they convert substances that inhibit their growth to non-toxic compounds for examples $S$. aureus produces the enzyme penicillinase which converts the antibiotic penicillin to penicillinoic acid which is no longer inhibitory to its growth (Singleton, 1999).

The observed antibacterial effect on the isolates is believed to be due to the presence of alkaloids, tannins, and flavonoids which have been shown to possess antibacterial properties (Draughon, 2004). Apart from antimicrobial activity exhibited by tannins, they also react with proteins to provide the typical tanning effect. Medicinally, this is important for the treatment of inflamed ulcerated tissues. Tannins have important roles such as stable and potent antioxidants (Trease et al., 1983). Most of the organisms used in this study were the causative agents of diarrhea and dysentery, and Euphorbia hirta inhibited the growth of the organisms. This is substantiated by the report of Kokwaro, 1993 which stated that $E$. hirta can be used in the control of diarrhea and dysentery. Since the plant appears to have a broad spectrum of action, they could be useful in antiseptic/disinfectant formulations and in chemotherapy. The results obtained support the fact that more work needs to be done on the purification, identification and quantification of the active components with the view of their use for in-vivo studies.

\section{CONCLUSION}

The aqueous and ethanol extracts of Euphorbia hirta show promise and can form a primary platform as an alternative therapy in the control of enteric pathogens.

\section{REFERENCES}

Akujobi, C., Anyanwu, B. N., Onyeze, C. and Ibekwe, V. I. (2004). Antibacterial Activities and Preliminary Phytochemical Screening of Four Medicinal Plants. J. Appl. Sci. 7(3); $4328-4338$.

Almagboul, A. Z., Farrog, A. A. and Tyagi, B. R. (2001). Sudanese plants used in folkloric medicine: Screening for antibacterial activity. Part X. Fitoter. 72: $810-817$.
Brantner A. and Grein E. (1994). Antibacterial activity of plant extract used externally in traditional medicine. $J$. Ethanopharmacol., 44(1): 35-40.

Cowan, S. T. and Steel, K. J. (1965). "Manual of Identification of Medical Bacteria". Cambridge University press. Pp 1-40.

De Boer, H. J., Kool, A. and Broberg, A. (2005). Antifungal and antibacterial activity of some herbal remedies from Tanzania. J. Ethnopharmacol. 96: 461-469.

Draughon, F. A. (2004). Use of Botanicals as Biopreservatives in Foods. Food Tech. 58(2); 20-28.

Simone, C. O., Adiukwu, M. U. and Okenta J. M. (1998). Preliminary Antimicrobial screening of the ethanolic extract from the lichen Usnea. Subfloridans (L). J. pharmaceutical. Res. Dev. 3(2):99-102.

Igoli, J. O., Ogaji, T. A., Tor-Anyiin and Igoli, N. P. (2005). Traditional Medicine Practice Amongst the Igede People of Nigeria. Afr. J. Trad. CAM. 2(2); $134-152$.

Jigna, P., Darshana, J., and Sumitra, A. (2005). "Efficacy of aqueous and methanol extracts of some medicinal plants for potential antibacterial activity" Turk. J. Biol. 29:203-210.

Kirtikar, K. R. and Basu, B. D.(1991). Indian Medicinal Plants, Periodical Experts Books Agency, $2^{\text {nd }}$ edition, vol. 3, New Delhi.

Kokwaro, J. O. (1993). Medicinal Plants in East Africa. 2 edn. East African Literature Bureau, Nairobi, Kenya

Kumar O.A., Naidu L.M. and Raja Rao K.G. (2010). Antibacterial Evaluation of Snake weed (Euphorbia hirta L.) J. Phytol. 2(3): 08-12.

Lind, E. M. and Tallantire, A. C. (1971). Some Common Flowering Plants of Uganda. Oxford University Press, Nairobi. p182.

Matu, E.N and Van Staden J. (2003). Antibacterial and anti-inflammatory activities of some plants used for medicinal purposes in Kenya. J. Ethanopharmacol., 87(1): 35-41.

Ming, L.C. (1999). .Ageratum conyzoides: A tropical source of medicinal and agricultural products. In: Janick, J.[Ed].Perspectives on new crops and uses. ASHS (American Society for Horticultural Science) Press, Alexandria, VA, USA. 469-473.

Ndip, R. N., Ajonglefac, A. N., Wirna, T., Ngwa, F., Mbullah, S. M., Tanih, N. F., Akoachere, J-FTK., Ndip, L. M., Luma, H. N., Wirmum, C. and Efange, S. M. N.(2009). In vitro antimicrobial activity of Cameroonian medicinal 
plants, on clinical isolates of Helicobacter pylori: Ageratum conyzoides. abstract PO 68) In: Proceeding of the 21st scientific congress of the Austrian Pharmaceutical Society, April 16 -18th, Vienna, Austria. Sci. Pharm. 77: 267

Nweze, E. I., Okafor, J. I. and Njoku, O, (2004). Antimicrobial activities of methanolic extracts of Trema guineensis (Schumm and Thorn) and Morinda lucida Benth used in Nigerian Herbal Medicinal Practice. J. Biol Res and Biotech. 2(1); $39-46$.

Ogbeche, A. K., Ajayi, G.O. and Onyeneta, P. (1997). Antibacterial activities of the leaf extract of Ageratum conyzoides. Nig. Quaterly. J. Hosp. Med. 7: 397-399.

Ogueke, C. C., Jude, N., Okoli, I. C., and Anyanwu, B. N. (2007). Antibacterial activities and toxicological potentials of crude ethanolic extracts of Euphorbia hirta, J. American Sci. 3(3):11- 16

Okwori, A. E. J., Dina, C. O., Junaid, S., Okeke, I. O., Adetunji, J. A., and Olabode, A. O. (2007). Antibacterial Activities of Ageratum conyzoides extracts on selected bacterial pathogens. Inter. J. Microbiol. 4: 1937- 1949.

Osadebe, P. O., and Ukwueze, S. E. (2004). A comparative study of the phytochemical and antimicrobial properties of the Eastern Nigeria species of African mistletoe (Loranthus micranthus) sourced from different host frees. J. Biol. Res. Biotechnol. 2(1):1823.

Patil, S. B. Naikwade, N. S., and Magdum, C. S. (2009). Review on phytochemistry and pharmacological aspects of Euphorbia hirta linn. JPRHC. 1(1):113-133.

Parekh, J. and Chanda, S. (2006). In-vitro Antimicrobial activities of Extracts of Launaea procumbens Roxb. (Labiateae), Vitis vinifera L. (Vitaceae) and Cyperus rotundus L. (Cyperaceae). Afr J Biol Res, 9:89-93.

Anon. (2005). The use of Euphorbia hirta in the treatment of sores, boils and wounds.

Sofowora, E. A. (1982). Medicinal plants and traditional medicine in Africa. John Wiley and sons LTD, Chichester. Pp 198.

Trease, G. E. and Evans, W. C. (1983). Textbook of Pharmacognosy. $12^{\text {th }}$ edition Balliere, Tindall, London, pp. 57-59, pp 343-383.

Wong-Ting-Fook, W. T. H. (1980). The medicinal plants of Mauritius. ENDA publication No. 10, Dakar.

Zakir H. K., Rowshanul H., Nikkon, F., Rahman, M., Rezaul K. M.(2009). Antibacterial and Antineoplastic Effect of Root of Euphorbia hirta L. Drug Invention Today 1(1): 10-12 